\title{
ACERCAMIENTO A UN DISCURSO PEDAGOGICO-RELIGIOSO DEL SIGLO XVI: LA CARTILLA PARA ENSEÑAR A LEER, DE FRAY PEDRO DE GANTE
}

\author{
Yamilet Solano
}

\begin{abstract}
This study represents a linguistic approach to one of the most valuable documents of the 16th C. (1569) for learning about the Spanish of New Spain. It focuses on two fundamental aspects: the semantic value of most of the verb forms as imperatives in pedagogical-religious discourse, and distributive enumeration as a basic rhetorical device for memorization.
\end{abstract}

Uno de los documentos más interesantes, dentro de la bastísima producción del siglo XVI en la Nueva España, es la Cartilla para enseñar a leer, de Fray Pedro de Gante. Se trata de un documento corto, de 16 páginas, con una o dos ilustraciones por página: estampas religiosas características de la época. En la portada aparece el título: "Cartilla para enseñar a leer", nuevamente enmendada, y quitadas todas las abreviaturas que tenía". Vemos una imagen religiosa grabada que representa a San Francisco de Asís recibiendo los estigmas de Jesucristo crucificado que aparece en el aire envuelto en alas de querubín. En la parte inferior de la portada, grabadas en xilografía, aparecen las letras del alfabeto en mayúscula, incluyendo cuatro al final que serán para escribir sonidos de la lengua mexicana que no tiene el español. Y al final del texto se lee: "México en casa de Pedro Ocharte, 1569 Años".*

Én el interior de la cartilla aparecen las letras del alfabeto en minúscula. Primero las consonantes. Luego las vocales. El paso siguiente es el silabeo: cada consonante combinada con las 5 vocales orales y después con las nasales para los respectivos textos en lengua mexicana. Inmediatamente siguen los textos fundamentales de la doctrina cristiana: el Peter Noster, Ave María, el Credo simbolizado con las imágenes de los apósteles con el texto en latín y la Salve Regina. Estas oraciones aparecen en las tres lenguas importantes de esa época en la Nueva España: romance (castellano), latín y lengua mexicana. Luego, solo en castellano aparecen: los Man-

\footnotetext{
Las citas del texto aparecen en español moderno para faci-
} litar su lectura. damientos de la ley de Dios, Los Mandamientos de la Santa Madre Iglesia, los Sacramentos de la Santa Madre Iglesia, la explicación de los pecados mortales y veniales, los cinco sentidos corporales y las obras de misericordia. Finalmente, otra vez en las tres lenguas, la confesión para ayudar a misa. Concluye el texto con algunas abreviaturas.

Hacemos la descripción del documento para demostrar que se trata de un texto pedagógico-religioso. Que su objetivo fundamental, su razón de ser, es enseñar a leer a los nativos para que pudieran aprender la doctrina (1).

También observamos en esta descripción que hay grandes saltos metodológicos: del silabeo al discurso. Esto podría parecernos inadecuado pero ese era el método que se usaba en la época y duró algunos siglos más. Texeda nos presenta un proceso similar en su famosa gramática y nos dice, al iniciar su trabajo, que la gramática española, como todas las demás, se compone de cuatro partes que son: letras, sílabas, dicciones o palabras y la oración, que es el discurso o plática (2). Todavía hoy parece que no ha cambiado mucho la metodología en las cartillas para enseñar a los indígenas: "Sin embargo, actualmente, a pesar de que la alfabetización tiene como criterio la enseñanza del español, los textos no han evolucionado mucho con respecto a las cartillas anteriores" (3).

De la cartilla y del autor tenemos a disposición muchos estudios que los ubican en su justa perspectiva y les dan el valor histórico-cultural, social, religioso y pedagógico que ambos merecen (4).

Según Icazbalceta, la Cartilla salió nuevamente a la luz en México en 1946 cuando el Dr. Emilio 
Valtón escribe unos artículos para Excelsior basándose en el facsímil completo que publicó Wagner en 1935 (5). Luego, en 1947 Valtón escribe la edición facsimilar en México con un copioso prólogo en el cual hace una presentación de la obra, un estudio bibliográfico y un estudio biográfico de fray Pedro de Gante con énfasis en su labor educativa y moral. Valtón exalta el valor de la cartilla:

"De todas las doctrinas y vocabularios impresos en México antes de esa fecha es el único que se ha encontrado, con la finalidad expresa de enseñar el alfabeto a los naturales. Es el CATON americano" (6).

Según Ignacio Márquez Rodiles, este es "el primer libro de texto" que vio la luz en América y que inicia la catequización y la alfabetización en forma organizada (7).

El aspecto político de la alfabetización en el siglo XVI está planteado y desarrollado con base en una copiosa bibliografía recogida por Shiley Brice Heath (8). El aspecto de la dominación ideológica que ejerce el discurso religioso es analizado en el estudio de Edelmira Ramírez (9). No hay duda de que ambos temas son importantísimos en la historia de América. Pero no vamos a polemizar porque creemos que la actitud y el trabajo de los misioneros eran coherentes con su época y estaban totalmente incorporados al sitema, razón por la cual los misioneros estaban convencidos de que cumplían con su deber y de que lo que hacían era lo mejor para los naturales. Los principios de la religión cristiana fueron "impuestos" con una gran seguridad por parte de los misioneros, creyendo que gozaban del privilegio de ejecutar los designios de Dios. Su objetivo y su mayor urgencia era evangelizar y el medio para lograrlo fue alfabetizar para que los indios pudieran leer la doctrina en su lengua nativa. Si pensamos en lo violento del choque de culturas podemos tener una idea del gigante esfuerzo y el estoicismo de los misioneros para lograrlo. La alfabetización tuvo que ser necesariamente improvisada e ingeniosa: simples sonidos, gestos, dibujos, jeroglíficos, cantos y la utilización de los niños para que los frailes pudieran aprender la lengua indígena y comunicarse (10).

El valor pedagógico de la obra de Fray Pedro de Gante es invaluable, aunque por razones obvias solo nos referimos a ella muy brevemente. Gante enseñó a los hijos de los principales en Texcoco, y en el Convento de San Francisco a los naturales. Aquí tuvo también una escuela secundaria o supe- rior en la que algunos alumnos sobresalientes se perfeccionaban en escritura, gramática castellana y latina (además de la mexicana), moral e historia sagrada. Los más sobresalientes no solo aprendieron lo fundamental sino que llegaron a dominar la gramática latina y leían las escrituras con gran fuidez, hecho que causó polémica entre los religiosos y los gobernantes. También se ocupó Gante de que los indígenas aprendieran un oficio y fundó un colegio de "artes y oficios" que, a criterio de muchos historiadores, fue un verdadero "politécnico". Además, en su escuela, Gante formó "maestros" pues de allí salían formados los muchachos que se encargaban de catequizar y alfabetizar por pueblos y barrios. El se encargaba de prepararlos y les ayudaba, en sus lecciones, a escribir sus pláticas y sermones. Pronto se hicieron indispensables a los españoles como traductores. Los indígenas mostraron una inteligencia tan extraordinaria que los españoles se sintieron amenazados y vieron en peligro su misión (11).

Es importante anotar que el valor pedagógico de la Cartilla de Gante ha sido valorado por especialistas actuales (12). En unos de esos trabajos se establece una comparación entre esa Cartilla y las que se usan actualmente para alfabetizar a los indígenas. Veamos la comparación:

1. Las cartillas actuales, en un porcentaje muy considerable, se presentan en dos lenguas (español y lengua indígena) y algunas de ellas en tres (español, lengua indígena e inglés), como ocurre en la de Gante: castellano, latín y lengua indígena.

2. Los materiales de la Colonia y en un alto porcentaje de las cartillas actuales se inician con el alfabeto en las lenguas presentadas; después se introducen grupos silábicos o palabras aisladas, y de pronto, sin gradación, se va del enunciado al párrafo, cuando no abruptamente al texto, sin discriminación alguna.

3. El interés de unos y otros materiales estriba en la alfabetización, y se olvida o se relega a un segundo plano de la enseñanza lo que significa que el alumno no adquiere las habilidades de la lectura y/o la escritura sin entender cabalmentee lo que lee y/o escribe.

4. Los materiales de hoy en día requieren de maestros bien adiestrados, o tan adultos y entregados como los misioneros de antaño" (13).

Con esta presentación queremos dejar justificado nuestro interés por este antiguo documento. 
Nuestro aporte será eminentemente lingüístico, ya que no hay, en todos los estudios consultados, un enfoque de esta naturaleza. Y no cabe duda de que este documento, como todos los documentos escritos en el siglo XVI en la Nueva España, nos permite observar particularidades lingüísticas muy importantes: la fonética y fonología (14), la estructura gramatical del discurso, y varios acercamientos al texto que se pueden hacer siguiendo los más diversos modelos de análisis. Pero por razones de tiempo y espacio solo nos detendremos en dos aspectos lingüísticos: la sintaxis verbal y un recurso retórico muy particular en este tipo de discursos, la enumeración distributiva. Nos parece que estos dos elementos son los que caracterizan en forma más evidente el tipo de discurso que nos ocupa, el pedagógico-religioso.

\section{La sintaxis del verbo}

El uso del verbo es uno de los elementos del discurso que más nos llama la atención en la Cartilla de Gante. Hay un predominio del imperativo y de las formas perfectivas. Y creemos que estos dos recursos, entre otros, caracterizan al discurso pedagógico-religioso, máxime en el siglo XVI y en la Nueva España.

Después de hacer el inventario de las formas verbales en el documento, obtuvimos el siguiente resultado: total 263 formas, que clasificamos de la siguiente manera: presente indicativo: 96 apariciones $(36.5 \%)$, pretérito simple, indicativo: 35 apariciones $(13.5 \%)$, futuro simple, indicativo: 13 apariciones $(4.9 \%)$, presente simple de subjuntivo: 12 apariciones (4.5\%), infinitivos: 75 formas (28.5\%), imperativo: 17 formas $(9.8 \%)$, gerundios: formas $6(2.2 \%)$.

Los datos de este inventario de formas gramaticales se altera de manera significativa cuando consideramos su significado en el contexto: los 12 subjuntivos tienen valor imperativo; de los 75 infinitivos 31 tienen valor imperativo y de los 13 verbos de futuro indicativo 11 son clarísimas formas imperativas. Total de uso del imperativo: 80 apariciones, que equivale a un $30.8 \%$. Esto implica que casi la tercera parte del total de los verbos que aparecen en el texto tienen este valor.

\subsection{Uso del presente simple de indicativo}

Es necesario observar el uso dominante de las formas del indicativo: en total 144, que constituyen un $54.15 \%$ de todos los verbos del texto.
También es importante hacer notar la frecuencia del uso del presente de indicativo, poco más de la tercera parte del total de los verbos: 96 apariciones, que equivale a un $36.5 \%$.

Desde el punto de vista semántico este uso del indicativo resulta muy significativo en este tipo de texto puesto que es el modo que enuncia una acción como pensada y ajustada a la realidad objetiva (15).

En esa forma se enuncia la acción pensada que se produce, se produjo o se producirá en la realidad. Y aunque esto ha sido muy discutido en la gramática (16) resulta adecuada para el texto que nos ocupa puesto que lo que dice la doctrina cristiana se debe aceptar como un hecho: “...el pecado mortal mata el cuerpo y el ánima internamente". Se enuncia una verdad, es un hecho el que se expresa verbalmente. Desde este punto de vista según el texto, es un hecho indiscutible que Jesucristo está "en los cielos" es "creador de los cielos y de la tierra" etc. Creemos que esta objetividad se busca y se logra mediante el uso del indicativo y que ese uso es necesario para los propósitos de un texto pedagógico-religioso. Debemos agregar que hay, en el texto, 29 elisiones de ser o estar como cópula y que no se incluyeron en el inventario porque no aparecen, lógicamente.

La forma de presente que domina en el texto es la que los gramáticos llaman presente general, que es el apropiado para expresar las verdades de carácter general, que se enuncian con independencia de toda relación temporal (17). En presente simple de indicativo se expresan las verdades intemporales (18), así, dos y dos son cuatro, pero fueron y seguirán siendo cuatro. Es necesario recordar el carácter normativo del texto. En él se establecen las condiciones que son obligatorias para una vida cristiana, las "reglas" del cristianismo: los mandamientos de la ley de Dios son...; los sacramentos de la Madre Iglesia son...; los pecados mortales son...; las obras de misericordia son... En cada uno de estos reglamentos se establecen las condiciones específiccas: el primero es...; el segundo es...; etc. Es importante señalar la presencia sistemática de ser y estar. De las 96 formas de presente de indicativo, 38 corresponden a ser o estar y hay 29 elisiones de estos verbos en función copulativa. Por un lado nos demuestra que el presente expresa un carácter neutro en cuanto al tiempo se refiere, por otro, coincide con el criterio de algunos gramáticos en cuanto a que la falta del verbo copulativo en español supone un carácter atemporal de la expresión (19) y, además, expresa juicios permanentes (20). 
"Los pecados mortales son siete. El primero, soberbía. El segundo, avaricia. El tercero, luguria".

"Los sacramentos son [...]. El primero, Bautismo. El segundo, confirmación, etc".

Este carácter atemporal y de permanencia de lo que se enuncia, es el que caracteriza todo el discurso: "Por el pecado pierde el hombre a Dios" implica una verdad absoluta tanto para el emisor como para el receptor del discurso, el hombre pierde a Dios, lo ha perdido y lo seguirá perdiendo siempre si está en pecado mortal. Cuando el texto dice que Jesucristo "está sentado a la diestra del Padre", es que estará eternamente sentado a la diestra del Padre.

\subsection{Pretérito perfecto simple}

De las formas de pasado, éste es el que predomina: 35 apariciones de verbos en pretérito, $13.8 \%$ del total de formas verbales, de las cuales solo tres son de las forma perifrástica he + participio y una sola imperfectiva: "yacían".

Ya señalamos el valor que tiene en el discurso por expresar el modo indicativo. Tal vez conviene agregar que también se le llama pretérito absoluto porque designa las acciones pasadas independientes de cualquier otra acción; es la forma absoluta del pasado (21). Cuando el texto dice que Jesucristo nació, padeció, descendió, resucitó, subió, prometió, redimió, se enfatiza la perfección de lo que se enuncia.

\subsection{Uso del futuro}

Registramos 13 formas de futuro simple de indicativo de las cuales solo dos tienen significado de futuro absoluto, y se trata de la misma forma verbal repetida, con metátesis en ambas ocasiones: "verna" por vendrá. Las otras once apariciones tienen claro significado imperativo.

Recordemos que el futuro se formó de una perífrasis que demostraba obligación: "amar-he". Puede decirse que implica propósito de realizar lo que se enuncia. En el texto aparece la forma moderna del verbo, y no aparece ninguna forma perifrástica, pero mantiene en todos los casos significado del futuro de mandato. El subtexto que contiene estas once formas es el de los diez mandamientos de la ley de Dios: Amarás a Dios, santificarás las fiestas, honrarás a tu padre y madre. Los otros siete mandamientos están en forma negativa, donde la negación obliga a usar el subjuntivo o el futuro puesto que no es posible en español el imperativo negativo (22): no jurarás, no matarás, no fornicarás, no hurtarás, no levantarás falsos, no desearás la mujer de tu prójimo, no desearás los bienes de tu prójimo. Luego dice que todos se deben resumir en un solo: amarás a Dios sobre todas las cosas.

El empleo del futuro en este tipo de discurso permite expresar la voluntad del emisor y la seguridad en el cumplimiento del mandato por parte del receptor.

\subsection{Uso del imperativo}

Esta forma verbal expresa la voluntad del hablante en la medida en que pretende controlar la voluntad y la conducta del receptor del mensaje. Este uso es particularmente significativo en un discurso como el de la Cartilla y en un contexto sociocultural que obligaba al uso de imperativos en todos los campos para llevar a cabo la gran empresa de la conquista y la colinización (23).

Es interesante observar cómo en forma imperativa solo aparecen diez verbos: danos nuestro pan, perdona nuestras deudas, líbranos del mal, ruega por nosotros, vuelve a nosotros tus ojos, muéstranos a Jesús, hágase tu voluntadd, venga a nosotros tu reino, perdóname.

Sorprende también en este tipo de discurso, que implica en muchos casos un diálogo con la Divinidad, el hecho de que no aparezcan las formas imperativas solemnes, propias del sermón e incluso del habla culta de la época (24): perdonad, libradnos, rogad, volved, etc.

La mayor parte de formas de imperativo se logran con formas verbales como el futuro, que ya comentamos, el subjuntivo y el infinitivo.

Las doce formas de subjuntivo que registramos en el texto están cargadas de connotaciones de exhortación o de ruego. La mayoría de ellas aparecen en la parte final de la Cartilla, en la confesión: "que seamos dignos; que sean apartados del mundo; que hagan bien; todo sea a tu santo servicio; que quiera rogar a su hijo; que me quiera perdonar; me guarde que no caiga en otros; me absolváis y me déis penitencia; con los cinco sentidos corporales que Dios me dio para que le sirviese y conociese".

El uso del subjuntivo es menos fuerte, desde el punto de vista de la relación emisor-receptor, que el empleo del futuro o del imperativo propiamente. Nótese que en estos casos es el creyente el que usa el subjuntivo en lugar de otras formas para rogar o suplicar a Dios o a la Virgen. En cambio, cuando 
el emisor es la Iglesia, vimos cómo se impone al creyente mediante el futuro de manera que no deja duda alguna sobre la obligatoriedad de los enunciados, se trata de imperativos de mandato. En los casos en que tiene valor exhortativo están dirigidos a una persona divina y depende de esa persona que la acción verbal se haga o no realidad; como cuando se manda a hacer algo "por favor".

\subsection{Uso del infinitivo}

Dentro de las formas con significado imperativo tenemos 31 infinitivos, casi la mitad del total de aparición. Esto es realmente impresionante en un texto tan breve. Y resulta impresionante porque parece que es característico de este tipo específico de discursos. Elizabet Luna, en su detallado estudio de los verboides registra 3.849 casos de infinitivo de los cuales solo tres están usados con valor imperativo (25) ninguno de estos tres presentan la estructura gramatical de los que aparecen en la Cartilla de Gante. Tampoco aparece en el exhaustivo análisis del Dr. Lope Blanch en el cual registra un número sorprendente de expresiones de mandato, pero no en infinitivo: "En mucha menor escala, aparece el infinitivo como forma de mandato" (26) pero no nos ofrece más que un ejemplo de infinitivo en perífrasis de subjuntivo utilizado como prohibición. Gili Gala registra el significado imperativo del infinitivo pero solo en las formas: ¡Sentaros! ¡Venid acá! (27).

La Cartilla trata de "artículos de fé" que todo cristiano debe cumplir. Son las normas de la doctrina: los mandamientos de la Ley de Dios y de la Iglesia, los sacramentos, las obras de misericordia, etc.

Observamos los diferentes tipos de estructura gramatical en que se presentan estos infinitivos de mandato:

a) Creer que + oración subordinada de infinito sin verbo regente, aunque cabe la posibilidad de que ese verbo sea una elipsis de SER: El primero, creer que es un hijo, creer que es padre, creer que es espíritu santo, creer que es criador, creer que es salvador, creer que es glorificado.

b) Infinito más $\mathrm{SN}$. (a veces sin la preposición del objeto directo del infinitivo): sufrir las injurias, consolar los tristes, rogar a Dios, oir misa, confesar a lo menos una vez..., pagar los diezmos, enseñar los simples, enterrar los muertos, etc. c) Infinitivo más oración subordinada introducida por el relativo "que": dar consejo al que..., castigar al que..., personar al que..., Estos infinitivos son de indudable sentido de obligatoriedad: "comulgar de necesidad para Pascua"..., "ayunar cuando lo manda...." Observamos que el primer artículo de la doctrina es CREER en un solo Dios, donde CREER tiene un incuestionable valor de mandato.

Podríamos suponer que en todas estas construcciones en infinitivo subyace un verbo regente: DEBE (creer, ayunar, comulgar, oir misa, confesar, etc.).

La abundante aparición del imperativo nos hace suponer que esta noción caracteriza al discurso religioso en la Cartilla que nos ocupa. Si ubicamos el documento en el contexto histórico-cultural, podríamos relacionar este fenómeno con la imposición ideológico-religiosa de la Iglesia y del poder civil para conformar las bases de las nuevas creencias en la Nueva España. Es obvio que la forma en que se usó el lenguaje tuvo una importancia crucial en el proceso de dominación. Pero también creemos que, aún sin relacionar el texto con el contexto histórico-cultural, el lenguaje de la doctrina seguiría teniendo el mismo valor y perseguiría los mismos objetivos. Sin embargo, para demostrarlo habría que comparar la Cartilla de Gante con la doctrina actual para ver si el lenguaje se ha modificado al modificarse el contexto extralingüístico. La abundancia de imperativos podría interpretarse como la expresión de la violencia de la colonización que subyace en el discurso. Sin embargo, nuestro interés es puramente lingüístico en este estudio.

Como pudimos ver, el uso más frecuente del infinitivo es con valor imperativo y tiene un significado vertebral en el análisis del discurso pedagógico-religioso.

Sin embargo, quedan otros usos del infinitivo que revisaremos a continuación.

En la confesión encontramos dos formas de infinitivo en perífrasis de subjuntivo con significado de posibilidad, casi es una exhortación a María y a Jesucristo: "que me quiera perdonar"; "que quiera rogar a su hijo".

También en la confesión encontramos una reiteración de infinitivos precedidos de la preposición en. Este recurso le da una musicalidad especial al discurso religioso, casi de letanía: “...que pequé en comer, en beber y reir, en jugar, en escarnecer, en mal decir, en mal pensar, en mal obrar y en mal perseverar...". 
Aparece el infinitivo de finalidad, precedido de la preposición por o para: por oír misa, por comulgar, por decir oración, para ayudar a misa.

Dos veces aparece "no tornar a pecar" con sentido futuro. Con este mismo valor y con intención volitiva encontramos "y prometo de vivir y morir en su santa fe".

\subsection{Uso del gerundio}

Registramos en el texto 6 formas de gerundio. Dos de ellos son adverbiales de modo: "A ti suspiramos gimiendo y llorando". Encontramos el gerundio para destacar el aspecto durativo: "que nació del vientre virginal de la virgen santa maría, siendo ella virgen antes del parto, en el parto y después del parto". “...que allá yacían esperando su santo advenimiento". Y en los otros dos casos significa acción causal, transitoria y coexistencia con el verbo subordinante: dice que el pecado mortal se perdona "por golpe de pecho diciendo..." “...y pierde el hombre a Dios [...] estando en pecado...".

\section{La enumeración distributiva}

No es necesario hacer un análisis detenido del texto para darse cuenta de que, además de la sintaxis verbal, se utiliza otro recurso que está presente en todo el texto y que nos parece que caracteriza a este tipo de discurso religioso: la enumeración distributiva. Creemos que este recurso no solo le da mayor coherencia al texto sino que es utilizado intencionalmente como mecanismo mnemónico porque le da un ritmo y una musicalidad especiales al discurso.

La enumeración, como figura de construcción, permite el desarrollo del discurso por la acumulación de expresiones que significan una serie de conjuntos o de partes de un todo (28).

Este recurso formal tiene como finalidad presentar los elementos de la doctrina conforme a un orden, un orden que le da la progresión al discurso y enfatiza su unidad, además de que lo hace adaptable al canto con gran facilidad. Debemos recordar que el canto fue un método que usaron los misioneros para que los indígenas recordaran y repitieran la doctrina. Motolinía dice que al principio se les enseñaba el "per signum crucis, el Paternóster, el Ave María, el Credo, Salve", "Todo cantado de un canto llano y gracioso", incluso, agrega que los diez mandamientos, los artículos de la fe y los sacramentos estaban en metro y se enseñaban cantados (29).
La primera enumeración de la Cartilla, aparece anunciada en el subtítulo "Los artículos de la fe: son catorce". Una vez que queda claro al receptor que deberán ser catorce artículos encontramos la primera distribución explícita: "Los siete pertenecen a la divinidad y los siete a la humanidad de nuestro señor..." Veamos cómo queda divido en dos partes el texto: siete artículos que pertenecen a un campo y siete a otro. Luego se pasa inmediatamente a enumerar los primeros siete; todos con la misma estructura gramatical: una forma verbal en infinito con valor de mandato:

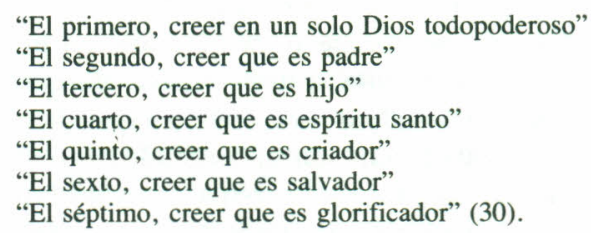

La enumeración continúa en los otros siete artículos restantes y la distribución es la misma pero no la estructura gramatical. Del segundo en adelante se suprime el verbo para evitar la repetición. Pero se aparece nuevamente en el cuarto para recordarle al receptor el valor imperativo del discurso para ser omitido en los mandamientos siguientes.

"El primero creer, que nuestro señor..."
"El segundo, que nació del vientre..."
"El tercero, que recibió muerte..."
"El cuarto, creer que descendió..."
"El quinto, que resuscitó..."
"El sexto que subió a los cielos...",
"El séptimo que vendrá a juzgar..."

Inmediatamente sigue en el texto otra enumeración perfectamente distribuida: los mandamientos de la ley de Dios. También en esta oportunidad se hace la aclaración de que no todos son de la misma naturaleza sino que los primeros tres pertenecen al honor de Dios y los otros siete al provecho del prójimo. Luego, en perfecto orden, encontramos cada uno de los elementos enunciados de antemano en el discurso. Obsérvese que al repetirse la misma estructura gramatical se crea una atmósfera particular, propia, casi de letanía:

\footnotetext{
"El primero, amarás a Dios.."

"El segundo, no jurarás..."

"El tercero, santificarás las fiestas..."

"El cuarto, honrarás a tu padre y madre..."

"El quinto, no matarás..."

"El sexto, no fornicarás..."

"El septimo, no hurtarás..."

"El octavo, no levantaras falsos"

"El noveno, no desearás la mujer..."

"El décimo, no desearás los bienes..."
} 
Los mandamientos de la Iglesia aparecen con una distribución casi idéntica, excepto que el mandato no está en futuro de indicativo sino en infinitivo:

"El primero oir misa"

"El segundo, confesar a lo menos..."

"El tercero, comulgar..."

"El cuarto, ayunar..."

"El quinto, pagar los diezmos..."

Todas las enumeraciones del texto aparece introducidas por un ordinal con artículo: el primero, el segundo, etc., pero hay variedad en la estructura gramatical del discurso, en cada uno de esos elementos que se enuncian. En los sacramentos de la Iglesia, como en los casos anteriores, se especifica que los sacramentos son siete pero no todos con el mismo valor: los cinco primeros son obligatorios y los dos últimos "son de voluntad". Al enumerar estos sacramentos encontramos que después del ordinal de rigor solo sigue un sustantivo con valor predicativo y hay elisión del verbo copulativo:

\footnotetext{
"El primero, bautismo..."

"El segundo, confirmación...

"El tercero, penitencia..."

"El cuarto, comunión..."

"El quinto, extrema unción..."

"El sexto, orden sacerdotal..."

"El septimo, matrimonio..."
}

En la explicación del pecado venial se dice que este pecado puede ser perdonado por nueve cosas. Cada una de esas nueve cosas aparecen ordenadas exactamente como en los casos anteriores, pero en estos casos hay elipsis del verbo regente "se perdona" y después del ordinal aparece una frase de finalidad introducida por la preposición "por".

\footnotetext{
"La primera, por oir misa"

"La segunda, por comulgar"

"La tercera, por bendición episcopal"

"La cuarta, por confesión general"

"La quinta, por agua bendita"

"La sexta por pan bendito"

"La septima por golpe de pecho diciendo..."

"La octava por decir la oración..."

"La novena por la palabra de Dios..."
}

En la misma parte del subtexto se continúa con la explicación del pecado mortal. Aquí la estructura del discurso es más compleja pero localizamos también una distribución introducida por una reiteración anafórica del verbo "perder". Esta reiteración aparece esta vez en lugar del ordinal y tiene como función enfatizar qué cosas pierde el cristiano que está en pecado mortal. La distribución anafórica en este caso, "y pierde" crea una atmósfera particular en el discurso y lo hace sentir como una amenaza.

"Y pierde el hombre a Dios que lo crio, y pierde la gloria que le prometio,

y pierde el cuerpo y el ánima que le redimió y pierde los méritos y beneficios de la santa madre iglesia".

Los pecados mortales también aparecen distribuidos por enumeración mediante el ordinal. Se trata aquí, nuevamente de una enumeración asindética: el ordinal, seguido de coma que sustituye al verbo ser y un $\mathrm{SN}$ : "El primero, Avaricia. El segundo, Lujuria. El tercero,..." Y luego vienen las siete virtudes a contrarrestar estos pecados. Entonces encontramos que, a esta figura formal se le suma una figura de pensamiento: la antítesis.

\footnotetext{
"La primera, la humildad contra soberbia"

"La segunda, largueza contra avaricia"

"la tercera, castidad contra lujuría" etc.
}

La antítesis se da explícitamente mediante la preposición "contra".

Las obras de misericordia también se expresan en el texto mediante la distribución de las acciones misericordiosas que el cristiano debe practicar; en estos casos se elide el ordinal.

\footnotetext{
"Enseñar a los simples"

"Dar consejo al que..."

"Castigar al que..."

"Perdonar al que..."

"Sufrir las injurias..."

"Consolar los tristes..."

"Rogar a Dios..."
}

Los enemigos del alma constituyen una enumeración asindética, totalmente explícita:



Y finalmente en la confesión para ayudar a misa aparece una enumeración muy significativa en el texto: se trata de la agrupación, por adición, de elementos que tienen una relación semántica muy estrecha porque todos son pecados, y lo son porque se ha incumplido con todas las normas establecidas en la doctrina y que han aparecido especificadas una a una en la Cartilla. Podemos afirmar que la Cartilla termina con una distribución recapitulativa. 
“[...] que pequé en comer, en beber y reir, en jugar, en encarnecer, en mal decir, en mal pensar y en mal obrar, y en mal perseverar, y en los siete pecados mortales [...] y en los diez mandamientos de la ley, y en los catorce artículos de la fe, y en las catorce obras de misericordia [...] y con los cinco sentidos corporales $[\ldots]$ y por cuanto hice o dije y consentí, encubrí, desencubrí desde..."

En todos los casos aquí expuestos podemos afirmar que este ordenamiento explícito del texto no solo busca la coherencia sino que es un recurso mnemotécnico muy bien logrado. Estas enumeraciones distributivas aparecen en todo el texto y parecen caracterizar el discurso religioso estudiado, la Cartilla de Gante, cuyo contenido básico es la doctrina cristiana. Además, este tipo de reiteración le da al discurso religioso un ritmo, una musicalidad y una monotomía a la vez que le permite ser recitado, cantado y memorizado.

\section{NOTAS}

( 1) Este tema de la temprana educación de los indígenas en México y sus consecuencias es ampliamente estudiado por José María Kovayashi. (Tesis doctoral). La educación como conquista. México: El Colegio de México. 1985 (2da. ed.).

( 2) Gerónimo de Texeda. Gramática de la lengua española (1619) Prólogo de J. Lope Blanch. México: UNAN. 1979. La cita aparece en la p. 4 del facsímil.

( 3) Gloria Ruíz de Bravo Ahuja. La enseñanza del español a los indígenas mexicanos. Materiales didácticos específicos. (Tesis doctoral). México: El Colegio de México 1976. Vol. I, p. 55.

( 4) Ver bibliografía.

( 5) Joaquín García Icazbalceta. Bibliografía Mexicana del siglo XVI. México: Fondo de Cultura Económica. 1954 p. 220 .

( 6) Emilio Valtón. El primer libro de alfabetización en América (1959). México: Antigua Librería de Robredo, 1947. Prólogo.

( 7) Academía Mexicana de Educación. Fray Pedro de Gante. Nota de Ignacio Márquez Rodiles. México. 1959.

( 8) Shirley Brice Heath. La política del lenguaje en México. México: SEP-INI. 1972. Caps. II y III.

( 9) Edelmira Ramírez Leiva. Análisis de un sermón barroco del siglo XVIII. (Tesis doctoral) México: UNAN. Facultad de Filosofía y Letras, División de Estudios Superiores. 1984 .

(10) Mendieta, Historia eclesiástica indiana. México: Editorial Salvador Chávez Hayhoc, (s.a.) Libro III. Cap. 13.
(11) Mendieta. Op. Cit. Vol. III. p.p. 62-71.

(12) Paula Alegría. La Educación en México antes y después de la conquista. México; S.E.P. 1963, p. 93 y sgts.

(13) Gloria Ruíz de Bravo Ahuja. Op. Cit., p. 55.

Además, ver cita de la misma autora en notas 3 y 4 de este trabajo. Fernando Lara y Ezequiel Chávez también han ahondado en la labor pedagógica de Gante, Véase la bibliografía.

(14) Claudia Parodi ha estudiado con detalle la fonética y lafonología del español del siglo XVI. Véanse:

"Para el estudio de la lengua traída a la Nueva España" en Anuario de letras. México: UNAN 1970. Vol. 8 p. 05-218 "Para el conocimiento de la fonética castellana en la Nueva España: 1523. Los sibilantes" en Actas del III Congreso de ALFAL. San Juan de Puerto Rico. Universidad de Puerto Rico 1976. -Lope Blanch ha hecho un estudio detallado del discurso del siglo XVI. El habla de Diego de Ordaz. Contribución a la historia del español americano. México: UNAN. 1985.

(15) Real Academia Española. Esbozo de una gramática de la lengua española. Madrid: Espasa Calpe. 1985. p. 454.

(16) O. Jespersen. Filosofía de la gramática. Barcelona: Anograma. 1968. p. 383.

(17) J. Roca Pons. Introducción a la gramática. Barcelona: Teide. 1960. p. 218.

(18) Gili Gaya. Curso Superior de Sintaxis Española.Barcelona: Bibliograf. S.A. 1985. p. 135.

(19) J. Roca Pons. Op. cit. p. 218.

(20) Gili Gaya. Op. cit., p. 58.

(21) Gili Gaya. Op. cit., p. 159.

(22) Real Academia Española. Op. Cit. p. 460.

(23) "Parecer ser este un momento histórico en que es necesario dar instrucciones, muchas y muy oportunas". Lope Blanch. Op. cit., p. 64 y p. 119 y sgtes.: se sorprende del elevado número de oraciones de imperativo en sus diferentes variantes.

(24) En El habla de Diego de Ordaz, ya citado, aparecen estas formas como predominantes: pedid, rogad, hazed, poned, etc.

(25) Elizabeth Luna Traill. Sintaxis de los verboides en el habla culta de la ciudad de México. México: UNAN. Instituto de Investigaciones Filológicas. 1980. p. 84.

(26) Lope Blanch. Op. cit., p. 119-120. En las notas de pie nos recuerda que el infinitivo tenía este valor en los Proverbios.

(27) Gili Gaya, Op. cit., p. 142-143.

(28) Helena Beristáin. Diccionario de retórica y poética. México: Editorial Porrúa S.A. 1985. p. 174-179. 
(29) Fray Toribio Motolinía. Historia de los indios de la nueva España. Barcelona: Herederos de Juan Gili 1914, p. 131.

(30) Hemos tomado todo textualmente, aunque modernizado, pero hemos puesto los artículos separados, sin quitar nada del texto, para que se pueda visualizar la enumeración con mayor claridad.

\section{BIBLIOGRAFIA}

Academia Mexicana de Educación. Fray Pedro de Gante. Nota introductoria de Ignacio Márquez Rodiles. México. 1959.

Alegría, Paula. La educación en México antes y después de la conquista. México: Secretaría de Educación Pública. 1963.

Alva Ixtlixochitl, Fernando de.Décima terce retación de la venida de los españoles y principio de la ley evangélica. México: Pedro Robredo, 1938. 104 págs.

Benítez, Fernando. La vida criolla en el siglo XVI. México: El Colegio de México, 1953. 322 págs.

Beristáin, Helena. Diccionario de Retórica y Poética. México: Editorial Porrúa S.A. 1985.

Carreño, Alberto María. Misioneros en México. México JUS, 1961.

Carrera Stampa, Manuel. Relaciones Geográficas de la Nueva España. Siglos XVI y XVII. México: Estudios de Historia Novohispana, 1968. 2 vols: 233 y 261 págs.

Cervantes de Salazar, Francisco. México en 1554. México: Andrade y Morales, 1975.

Crónicas de la Nueva España. Madrid: Gráficas Vagüís, S.L., 1971, 2 Vols. (I Vol. 442 págs., II Vol. 311 págs.)

Clavijero, Francisco Javier. Historia Antigua de México: Sacada de los mejores historiadores españoles y de los manuscritos y de las pinturas (trad.. del italiano por G.G. de Moca). Londres R. Ackermann, 1826. 416 págs.

Cortés, Hernán. Historia de la Nueva España. México: Joseph Antonio de Hogal, 1770. 400 págs.
Chavéz, Ezquiel. El primero de los grandes educadores de la América. Fray Pedro de Gante. México: Mundial, 1934. 106 págs.

De la Torre Villar, Ernesto. Fray Pedro de Gante, Maestro y Civilizador de América. México: UNAN. Instituto de Investigación Históricas Vol. V. 1974.

Durán, Diego-Fray. Historia de las Indias de Nueva España y islas de Tierra Firme. México: J.M. Andrade y F. Escalante, 1867. 2 Vol. (525 y 477 págs) y Atlas.

Gallegos Rocafull, J. Manuel. El pensamiento mexicano en los siglos XVI y XVII. México: UNAN, Centro de Estudios Filosóficos; 1951.

García, Genaro. El Clero de México durante la dominación española, según el archivo inédito archipiscopal metropolitano. México: Librería de la Vda. de Ch. Bowret, 1907, 269 págs.

García Icazbalceta, Joaquín. Bibliografía Mexicana del siglo XVI. México: Fondo de Cultura Económica. 1981. 589 págs.

Cartas de religiosos de Nueva España de 1539 a 1594. México: Librería de Andrade y Morales. 1856. 198 págs.

Colección de Documentos para la historia de México. México: J.M. Andrade, 1858. 2 Vols. (544 y 600 págs.).

La instrucción pública en México durante el siglo decimosexto (discurso) s.p.i. 91 págs.

García Méndez y Desgardin, Raquel. Las crónicas religiosas del siglo XVI. México: Museo Nacional de Arqueología, Historia y Etnografía. 1930; 42 págs.

Gili Gaya, Samuel. Curso Superior de Sintaxis Española. Barcelona: Bibliografía S.A. 1985.

Gómez Canedo, Lino. Evangelización y conquista: Experiencia Franciscana en Hispanoamérica. México: Porrúa 1977, 393 págs.

La educación de los marginados durante la época colonial. México: Porrúa, 1982425 págs. 
Gómez de Cervantes, Gonzalo. La vida económica y social de Nueva España al finalizar el siglo XVI. México: Antiguas Libr. Robredo de José Porrúa. 1944. 218 págs.

Heat, Shirley Brice. La política del lenguaje en México: De la Colonia a la Nación. México: Instituto Nacional Indigenista. 1972. 317 págs.

Jespersen, Otto. Filosofia de la Gramática. Barcelona: Anagrama. 1968.

Kovayashi, José María. La educación como conquista. México: El Colegio de México. 1985. 295 pág.

Lara Contreras, Fernando. Pedro de Gante en la Educación de México. México: El Colegio de México (Tesis) 1969.

Lope Blanch, Juan M. El habla de Diego de Ordaz. Contribución a la Historia del Español Americano. México: --UNAM. Instituto de Investigación Filológicas. 1985. 231 pág.

Luna Traill, Elizabeth. Sintaxis de los verboides en el habla culta de la Ciudad de México. México: --UNAM. Instituto de Investigaciones Filológicas, 1980. 241 pág.

Mendieta, Gerónimo de, Fray. Historia Eclesiástica Indiana. México: Edit. Salvador Chávez Hayhoc, (S.A.) 4 vols.

Millares Carlo, Agustín. Repertorio Bibliográfico de los Archivos Mexicanos y de las Colecciones Diplomáticas fundamentales para la Historia de México. México: Aldina, 1948. 186 pág.

Motolinia, Toribio. Historia de los Indios de la Nueva España. Barcelona: Herederos de Juan Gili, 1914. 282 pág.
Osorio Romero, Ignacio. Floresta de gramática, poética y retórica en la Nueva España (15211767). México: UNAM. Instituto de Investigaciones Filológicas. 1980. 431 pág.

Parodi, Clauda. "Para el conocimiento de la fonética castellana en la Nueva España: 1523. Las sibilantes". En: Actas del III Congreso de ALFAL San Juan de Puerto Rico. Universidad de Puerto Rico, 1976.

"Para el estudio de la lengua traída a la Nueva España". En: Anuario de Letras. México: UNAM Instituto de Investigaciones Filológicas. 1970. Vol. 8.

Ramírez Leivs, Edelmira. Análisis de un sermón barroco del siglo XVIII. (Tesis doctoral) México: UNAM. Facultad de Filosofía y Letras. 1984.

Real Academia Española. Esbozo de una nueva Gramática de la Lengua española. Madrid: Espasa-Calpe. 1985.

Ricard, Robert. La Conquista Espiritual de México: Ensayo sobre el Apostolado y los Métodos Misioneros de las Ordenes Mendicantes de la Nueva España.

Roca Pons, J. Introducción a la Gramática. Barcelona: Teide. 1960.

Ruíz de Bravo Ahuja, Gloria. La enseñanza del español a los indígenas mexicanos. Materiales Didácticos específicos. (Tesis doctoral). México: El Colegio de México. 1976. 2 Vol.

Sahagún, Bernardino de. Historia General de las Cosas de la Nueva España. México: Alejandro Valdés, 1829. 3 Vol. (408 pág., 355 pág y 438 pág). 